\title{
Perceptions of the Process of Work in a Psychosocial Care Center for Children and Youth
}

\author{
Meyrielle Belotti ${ }^{1}$ \\ Departamento de Terapia Ocupacional and Programa de Pós-Graduação em Psicologia, \\ Universidade Federal do Espírito Santo, Vitória, ES, Brazil \\ Bruna Ceruti Quintanilha \\ Kelly Guimarães Tristão \\ Pedro Machado Ribeiro Neto \\ Programa de Pós-Graduação em Psicologia, Universidade Federal do Espírito Santo, \\ Vitória, ES, Brazil \\ Luziane Zacché Avellar \\ Departamento de Psicologia Social e do Desenvolvimento and Programa de Pós-Graduação \\ em Psicologia, Universidade Federal do Espírito Santo, Vitória, ES, Brazil
}

\begin{abstract}
The aim of this article was to analyze the perceptions of health professionals regarding the process of work and the production of care after the merging of a Psychosocial Care Center for Alcohol and Drug Use for Children and Youth (CAPS ADi) and a Psychosocial Care Center for Children and Youth (CAPSi), in a city located in southeastern Brazil. This was achieved using a qualitative approach. The study involved 11 health professionals. Data were collected using focus groups, and examined using content analysis. The results indicated that the merging of the services was implemented in a top-down fashion, with health professionals excluded from the planning of the merger. This had a significant impact on work performance, leading to difficulties in adopting an interdisciplinary approach to multidisciplinary work; lack of commitment; and a division of the work according to patient needs. Additionally, the exclusion of health professionals from the process of change was identified as a significant cause of distress for these individuals.
\end{abstract}

Keywords: Work process, mental health services, child, adolescent.

\section{Percepções sobre o Processo de Trabalho em um Centro de Atenção Psicossocial Infanto-Juvenil}

\section{Resumo}

O objetivo da pesquisa foi analisar as percepções dos profissionais de saúde sobre o processo de trabalho e, consequentemente, a produção do cuidado, diante da fusão de um Centro de Atenção Psicossocial Álcool e Drogas infanto-juvenil (CAPS ADi) com um Centro de Atenção Psicossocial Infanto-juvenil (CAPSi), de um município da região sudeste do Brasil. Utilizou-se a abordagem qualitativa. Participaram do estudo 11 profissionais de saúde. Para a coleta de dados foi utilizado a técnica do grupo focal. Os dados foram submetidos à análise de conteúdo. Os resultados indicam que a fusão dos serviços ocorreu

1 Mailing address: Rua Nancy Alves Vieira de Menezes, 50, Mata da Praia, Vitória, ES, Brazil 29.065-560. Phone: (27) 3022-6861 (27) 99949-3596. E-mail: meyri.belotti@gmail.com 
de modo verticalizado, não havendo a inclusão dos profissionais no processo de planejamento para a unificação. Esta situação produziu reflexo no trabalho, tais como: dificuldades para a realização do trabalho em equipe sob a ótica da interdisciplinaridade; a construção de um agir descomprometido; e a organização do trabalho por demandas. Além destas questões, verificou-se que a não apropriação dos profissionais dos processos de mudança ocorridos gerou sofrimento nestes.

Palavras-chave: Processo de trabalho, serviços de saúde mental, criança, adolescentes.

\section{Opiniones en el Proceso del Trabajo en un Centro de la Atención Psicossocial Infanto-Joven}

\section{Resumen}

El objetivo del artículo es analizar las opiniones de los profesionales de salud en el proceso del trabajo e la producción del cuidado, delante de la fusión de uno Centro de la Atención Psicossocial Alcohol y Drogas Infanto-Joven (CAPS Adi) con uno Centro de la Atención Psicossocial Infanto-Joven (CAPSi), de una ciudad de la región del sudeste del Brasil. Se utilizó un enfoque cualitativo. Once profesionales de salud habían participado del estudio. Para la recogida de datos fue utilizado la técnica del grupo focal. Los datos habían sido sometidos al análisis del contenido. Los resultados indican que la fusión de los servicios ocurrió de manera jerárquica, y no hay inclusión de los profesionales en el proceso de planificación para la unificación de los servicios, como: dificultades para llevar a cabo el trabajo en equipo desde la perspectiva de la interdisciplinariedad; la construcción de acciones sin compromisos; y también la organización del trabajo para las demandas. Además, se ha descubierto que la no apropiación de los profesionales en los procesos que se produjeron causaron sufrimiento.

Palabras clave: Proceso del trabajo, servicios de la salud mental, niño, adolescente.

The mental health system has undergone significant reform in recent years, leading to substantial changes in knowledge and practice in an attempt to overcome the asylum model. These changes began with a restructuring of public policy and a reorganization of the health care system to allow for the provision of extended care, both to those in psychological distress and those whose issues stem from the abuse of alcohol and other drugs (Ministry of Health, 2009a, 2009b, 2009c, 2014).

Psychosocial support therefore became the guiding principle in this model of care, which is based on new concepts and conceptions, and their articulation with other forms of knowledge of psychological distress (Luzio \& Sinibaldi, 2012). As a result of this paradigm shift, other forms of dealing with the experience of madness must be created by reformulating technical interventions to focus on the following: promoting the reorganization of services; acknowledging the person in psychological distress as an individual with their own personal history and desires; and facilitating the creation of health care strategies with a social inclusion approach, which deals with the stigma of mental illness and the use of alcohol and other drugs.

Unfortunately, these issues took much too long to be addressed by public policy on child and adolescent mental health care, which consisted mainly of an extension of public policies for adult populations (Lima, 2014). As a result, the care of children and adolescents often fell to total institutions run by private or philanthropic organizations, most of which function in a fragmented way (Cavalcante, Jorge, \& Santos, 2012).

Psychosocial support is also the guiding principle for the care of individuals with issues related to alcohol and drug abuse. However, in addition to this principle, the model of care for this population also involves harm reduction strategies. According to the Ministry of Health, harm reduction principles should provide an 
ethical compass for all services provided by the Brazilian public health system (2009c). In contrast with the abstinence model of treatment, harm reduction seeks to minimize the biological, social and economic consequences of drug use, respecting the individual and their right to use psychotropic substances.

One of the main changes to the organization and structure of public health policy was the creation of the Psychosocial Care Network (Rede de Atenção Psicossocial [RAPS]), which aimed to extend the access of individuals in psychosocial distress and with issues related to alcohol and drug use to available services ${ }^{2}$ at all levels of complexity, while ensuring the integration and articulation of these services (Ministry of Health, 2014). The implementation of the RAPS inevitably changed the configuration of mental health services in the public system. The CAPSi were created to assist children and adolescents with severe and persistent mental illness, as well as those with issues related to the use of alcohol and other drugs.

According to the guiding principles of the RAPS, the work at the CAPS must be carried out by a multidisciplinary team and approached in an interdisciplinary fashion (Ministry of Health, 2014). Interdisciplinarity is a form of multidisciplinary work characterized by a more advanced relationship between areas of knowledge, in which disciplinary boundaries are breached in favor of collaboration and complementary efforts (Sousa \& Bastos, 2016). In addition to interdisciplinary, Tavares, Vendrúscolo, Kostulski, and Gonçalves (2012) describes other forms of interaction between areas of knowledge, including multidisciplinarity, whereby professionals from different areas approach a similar theme

2 The main components of the RAPS are the following: Basic Health Units; Family Support Centers. Mobile Clinics ("Consultórios da rua"); Community Centers; Psychosocial Care Centers, in all their different forms; Urgency and Emergency Services; Shelters; Home-care services; Inpatient care for those struggling with mental illness, alcohol and other drugs at General Hospitals and Residential Treatment Services (Ministry of Health, 2014). or problem in parallel, without collaboration or close communication, as well as transdisciplinarity, in which all relationships are horizontal, and multiple areas of knowledge converge upon a shared premise, which implies the construction of a novel disciplinary perspective.

The implementation of the RAPS also led to an additional change in the health-care process, which is now left to the responsibility of the CAPS or Basic Health Care services, ensuring the long-term follow-up of each case and a permanent process of co-management (Ministry of Health, 2014). Co-management is an ethicalpolitical principle of the National Humanization Policy (Política Nacional de Humanização $[\mathrm{PNH}])$, which deals with the inextricable connection between the production of health care and the management of work processes. The comanagement model provides a framework for the organization of work processes through the use of teamwork, ensuring equal power sharing through collective discussion and decision-making (Ministry of Health, 2009a).

The PNH highlights the need to reorganize work processes in order to enhance the offer of health care services. Work processes can be defined as the way in which professional activity is carried out, or the "set of procedures through which people use the means of production to act on an object in order to transform it into an ostensibly useful product" (Faria, Werneck, Furquim, Santos, \& Teixeira., 2009, p. 21).

The work process in health care has its own particularities, and the actions of the workers demonstrate how the object of work will be transformed. As a result, due to the variety of human needs addressed by these professionals, health care work is not controllable (Littike \& Sodré, 2015).

The present article derives from the study of a CAPSi in southeastern Brazil. Its relevance lies in the fact that this particular service experienced a unique process in the form of a merger with another institution, a Psychosocial Care Center for Alcohol and Drug Use in Children and Youth (CAPS ADi). As a result, the CAPSi provides assistance to children and adolescents with both severe and persistent mental illness, 
and issues related to the use of alcohol and other drugs, in the same institution. In light of these events, the aim of this study was to analyze the perception of health care workers of the effects of the merger on their work process and, consequently, on the production of health care.

\section{Method}

The aim of this study was to comprehend the perception of health professionals of the effects of the merger on their work process and the care provided to service users. A qualitative approach was selected as the most appropriate method for addressing this objective. Qualitative research focuses on the comprehension of meanings, intentions and the inherent subjectivity of actions, attitudes, relationships and social structures (Minayo, 2012).

Data were collected using the focus group method, which encourages the interaction between participants based on topics selected by the researcher (Busanello et al., 2013). This approach provides an environment which facilitates discussion and allows participants to express their perceptions, beliefs and attitudes toward the topic at hand (Minayo, 2012).

The study location was selected due to previous partnerships between the health service and the researchers as part of other studies and projects, whereby researchers became aware of the merger between the service and the CAPS ADi. The aim of the study was introduced to professionals in a team meeting, in which all were invited to participate in focus groups at the health service itself.

The study involved 11 participants: four psychologists, two social workers, one nurse technician, two occupational therapists, one physician and one physical educator. Due to scheduling conflicts, the sample was divided into two groups, each of which took part in two sessions, lasting approximately one hour. Sessions were separated by 15-day intervals. The discussions focused on the following topics: (a) the merging process; (b) the organization of the service after the merger; (c) difficulties in the process; (d) structuring care strategies in the new environment.

Discussions were examined by content analysis, as described by Bardin (2006). Content analysis provides a method for the systematic analysis of the messages transmitted through communication (Bardin, 2006). This process was performed in the following steps: (a) preanalysis; (b) exploration of the material and (c) analysis of the results. The first step involved a preliminary reading of the transcriptions, and the selection of relevant excerpts. In the second stage, categories were defined based on the excerpts selected. A total of five categories were obtained. The last step involved predictions and interpretations based on the data, guided by the categories identified.

Each category was illustrated by excerpts from the focus group discussions. Speakers were given a label consisting of a capital letter $\mathrm{S}$ followed by a number (i.e. S1, S2, S3, etc).

The study was approved by a research ethics committee and the Municipal Department of Health. All professionals provided written consent for participation, as per Resolution no. 466 (2012) of the National Health Council.

\section{Results and Discussion}

As previously mentioned, the data revealed five categories: (1) Reasons for the merger; (2) The merging process and work organization; (3) The stigmatization of mental illness and psychoactive substance use; (4) Teamwork; and (5) The production of care at the CAPSi. Results will be discussed as they are presented.

\section{Reasons for the Merger}

This category included all statements regarding participants' understanding of the reasons for merging the two services. One of the reasons mentioned was the lack of regulatory policy for the CAPS ADi, and the absence of data to justify its existence:

"It doesn't exist in Brazil, the CAPS ADi. Not in public policy. The CAPSi is supposed to care for both populations, it makes no sense to have two separate services" (S. 3). 
"What was the basis for creating the CAPS ADi? And what is the justification for putting an end to its activities? See, there is none. So it seemed like it was done on a whim" (S. 7).

As previously mentioned, after the RAPS was implemented, the CAPS took up responsibility for the care of individuals with severe and persistent mental illness, including those whose problems stemmed from the use of alcohol and other drugs. According to these new guidelines, all children and adolescents who use psychoactive substances must be assisted at the CAPSi, or, alternatively, at CAPS AD or CAPS AD III services directed at children and adolescents; that is, although public policy does not specifically mention a "CAPS ADi," its function can be performed by existing services such as the CAPS AD and CAPS AD III.

The absence of data to justify the creation and continued existence of a CAPS ADi can be attributed to the non-existence of an electronic mental health information system, and the absence of information regarding mental illness in the Basic Health Information System (Sistema de Informação da Atenção Básica [SIAB]). The aim of Health Information Systems (Sistemas de Informação em Saúde [SIS]) is to provide comprehensive data on patient follow-up, and contribute to ongoing evaluations of population health and intervention outcomes, all of which are essential for resource management, control, and allocation. The SIAB is an SIS that contributes to the follow-up and evaluation of activities performed at a primary care level (Ministry of Health, 2009b).

The absence of data to on which to base mental health care planning, monitoring, evaluation and decision-making leads services/interventions to be implemented as if "on a whim".

Another reason for the merger, according to the perception of the focus groups, was the need to strengthen adult mental health services in the municipal health system:

When the CAPS ADi first opened, there was a lot of... Anger in the system as a whole: how come? If for years we've needed a second CAPS III for adults, how could you go and set up a CAPS ADi? (S. 9)
Studies (Couto, 2012; Lima, 2014) suggest that the application of psychiatric reform principles to mental health care in children and adolescents occurred much too slowly in Brazil. Additionally, according to Couto (2012), pediatric mental health was always second to adult mental health with regards to the production of care. Lima (2014) suggests that this reinforces the idea of pediatric mental illness as a disability. The author emphasizes the importance of acknowledging mental illness in children and adolescents, so that pediatric mental health can "get of out the doldrums," as did the adult mental health system.

\section{The Merging Process and Work Organization}

This category included all descriptions of the merging process itself, and its impact on the attitudes of health care professionals. The focus group discussions revealed that health care workers played no part in planning or decisionmaking at any point during the merging process:

Management did not listen to the teams. It was imposed on us. They decided it, implemented it, and the change happened... At first it was very difficult for both teams. It was distressing. How is it going to be? To this day there are still some difficulties in conducting the work. (S. 8)

These statements demonstrate the fragility of the co-management model and the dominance of a vertical management structure, which prevented health care workers from adapting to their work environments. This generated significant distress, as well as several difficulties in work organization. According to Morschel and Barros (2014), the PNH is unique in its attempt to encompass both training and practice in health care. The authors believe that the implementation of this policy results in new forms of work organization which contrast with existing institutionalized models, bridging the gap between those who think and those who do, those who plan and those who execute.

The focus groups also noted that, in the period following the merger, although both services shared the same physical space, their functions 
were largely distinct; that is, children and adolescents with issues related to the use of alcohol and other drugs were still cared for by the former employees of the CAPS ADi. The opposite also occurred, with children and adolescents who suffered from mental illness being referred to professionals who had worked in the CAPSi when its services were still limited to children and adolescents in psychological distress:

“... The services merged, but didn't mix..." (S. 10).

... to this day there are some people who don't treat alcohol and drugs. It's obvious and glaring, the patient gets there and then, 'Hey, go get so-and-so, there's a patient here for him'. They don't try and do it themselves. (S. 1)

The detachment shown in this situation is also a consequence of vertical management. According to Cunha and Magajewski (2012), the inclusion of health care workers in the management process is crucial to promoting collective responsibility and producing changes in the health care model. Overall, there has been little incentive to include health professionals in comanagement efforts. This reduces the opportunities for developing critical thinking skills and new ways of working in health care, in which the responsibility for delivering effective care is equally shared by all.

The appreciation of all those involved in the production of care provides a way to reaffirm public health guidelines. At the same time, it ensures the motivation, reflection and creativity of health care workers, while minimizing their suffering and promoting self-esteem (Cunha \& Magajewski, 2012).

\section{The Stigmatization of Mental IIIness and Psychoactive Substance Use}

The social connotations of mental illness, as well as drug and alcohol use in children and adolescents, were also discussed by the focus groups. Data analysis revealed several difficulties in engaging users of the former CAPS ADi into treatment at the CAPSi due to discriminatory and exclusionary social attitudes toward madness:
"There are still issues like, 'I don't want to go to the CAPS. That's for crazy people", (S. 2).

Despite efforts to introduce changes in the production of care and strategies for the social inclusion of people in psychological distress, mental illness is still surrounded by stigma. The stigmatization process hinders the construction of a new place for the mentally ill in society. There is therefore a need to establish new ways of relating to those thought to be "crazy" (Belotti \& Lavrador, 2016). In other words, these individuals must be allowed to occupy different spaces in the city; provided with adequate living conditions, education and employment; encouraged to form collective organizations, such as cooperatives and associations, together with their family members, among other initiatives.

Negative attitudes toward children and adolescents with issues related to alcohol and drug use were also discussed. These individuals are often stigmatized, and seen as dangerous, "negative" influences, promoting drug use in those around them. There is therefore a wish to maintain a social distance from these individuals:

The mothers of some children with mental disorders were scared when they saw the adolescents who used alcohol and drugs. Wait a minute, So these boys are going to be here, too? I keep my son away from drugs, now I leave him here with them? (S. 5)

According to Ronzani and Andrade (2014), several factors may facilitate the stigmatization of individuals with issues related to alcohol and drug abuse. These individuals are often seen as having low self-esteem and personal weaknesses, and given full responsibility for their issues with alcohol and drugs. In addition to struggling with these "labels," these individuals also face significant moral condemnations, which hinders the implementation of "adequate" interventions (Ronzani \& Andrade, 2014).

Although both populations seen at the CAPSi were subjected to social stigma, the focus groups also discussed the beneficial effects of personal contact on the reduction of negative attitudes toward mental illness and children and adolescents with issues related to alcohol and drug use: 
“. . . Eventually, the mothers themselves realized it wasn't like that. That those who use alcohol and other drugs also need help" (S. 10).

". . . As time went by, they began to understand and respect the way those with mental disorders worked" (S. 9).

Rüsch, Angermeyer, and Corrigan (2005) suggested that personal contact and interaction with stigmatized populations can be used as a strategy to reduce stigma. The authors also emphasized the importance of educational initiatives in replacing myths with information and encouraging society to question and challenge stereotyped attitudes and behaviors.

The promotion of strategies to reduce stigma requires interventions on a macro level, through public policy, for instance. However, the demystification of madness and issues related to the use of alcohol and other drugs cannot be achieved by macro-level strategies alone. There is also a need for interventions on a micro-level, that is, in the daily life of institutions and their practices, so they can help produce change in peoples' lives.

\section{Teamwork}

Statements regarding interdisciplinary relationships and teamwork were classified into this category. Descriptions of the interdisciplinary relationships between health professionals reveal significant contradictions. Some statements suggest that teamwork is organized in shifts, with the service actually comprising several different teams. Others suggest that the relationships between areas of knowledge is far more variable:

"There are three teams in here. Putting everyone together doesn't mean turning them into a single team. There's the morning shift, the afternoon shift, and we are the in-between shift, who work for 8 hours" (S. 8).

"Do we have to be just trans- or just multi? Let's be a constant metamorphosis..." (S. 3).

As previously stated, work organization and interdisciplinary relationships in health care teams can take on many different forms. There is multidisciplinarity and pluridisciplinarity on one end, with little to no contact between areas of knowledge, and interdisciplinarity and transdisciplinarity on the other, with significant in- teraction between them (Sousa \& Bastos, 2016; Tavares et al., 2012).

The first statement describes the existence of three different teams, whose members may interact with each other, but not with colleagues in the other teams. The second statement describes teamwork as a "constant metamorphosis", in which the work organization oscillates between multi-, inter- and transdisciplinarity. This is reflected by the experiences of the team itself:

Sometimes, we're euphoric. Things are advancing, moving forward. We feel like it's only going to get better, like maniacs. Then sometimes we're down, disheartened, hopeless. And we think it's only going to get worse. So these things come up in the team. The team isn't always moving forward, improving. And it's not always at the end of its rope, broken down. We have to know how to deal with these moments in the team. (S. 1) These data also highlight the need to preserve specialized work groups, without sacrificing flexibility and knowledge-sharing:

I'm using his knowledge, and allowing him to share mine. But without overriding his knowledge or him overriding mine. How far can I take my knowledge without overriding that of my colleague? How far can I let his knowledge into my practice? (S. 5)

Specialized work teams allow each professional to apply the knowledge and practices specific to their area of work, granting them autonomy, while also fostering interdependence (Sousa $\&$ Bastos, 2016). Nevertheless, specialized teams could not handle the demands of the health care system on their own, and flexible collaboration between fields would have to be established to ensure the delivery of integrated care.

Subjective aspects of day-to-day teamwork were also identified in this category. These issues were found to influence the development of work processes:

It's a construction, involving the best and the worst of human beings: vanity, selfishness, narcissism, hatred, envy. When we come together, all of that is in play. How to use it to build something that becomes a working tool for us. (S. 4) 
Nardi (2006) introduced the idea of subjectivity as a strategic concept in social psychology, which captures the inextricable link between the individual and the collective, the inside and the outside, the person and society. In light of this information, the author states that work processes in health care cannot be analyzed based on the purely technical process of production, but should also consider the way in which subjects experience and give meaning to their work.

Franco and Merhy (2012) suggest that the micropolitics of work processes in health care reveal a dynamic, creative, and unstructured world with high inventive potential; that is, the production of care is a social and subjective phenomenon. The authors therefore acknowledge that the productive life is organized around relationships and that the daily actions of workers are permeated by their relationship with their environment. As a result, teamwork and, consequently, the production of care occur in the midst of multiple determinations, whose meanings are constantly articulated and negotiated, without necessarily resulting in coherent action.

\section{The Production of Care at the CAPSi}

Clinical practice and the production of care were also discussed in the focus groups. As reflected in the comments below, health professionals identify certain differences between the clinical management of children and adolescents in psychological distress and those with issues related to the use of alcohol and other drugs:

As for the point of convergence between the clinics... That's a challenge. I think the technical sector wasn't sensitive enough, as they didn't alert the managers to the differences between clinical practice with alcohol and drugs, and mental illness. The challenge is how to reconcile them. (S. 6)

They are different practices, but they have a lot in common, see. Like the issue of social insertion, schools... The family issues too. The complexities are very similar, we have a lot in common. The difference is in the clinical management, the one-on-one. That really is different. (S. 11)
As previously stated, the production of care in mental health is guided by a psychosocial care model. Harm reduction strategies are also involved in cases involving the use of alcohol and other drugs. However, in addition to these strategies, pediatric mental health must also consider the particularities of the system surrounding the child or adolescent, and must include additional sectors in the production of care, such as basic health care, education, social work, as well as the justice and legal systems (Couto, 2012; Lima, 2014; Ministry of Health, 2014). There is also the need to include the family in the treatment process, to use the appropriate language, and offer play-based interventions (Avellar \& Bertollo, 2008; Guerra, 2005).

As such, "the points of convergence" between the clinical care of children and adolescents in psychological distress, and those with issues related to alcohol and other drugs, are the psychosocial care model and the particularities of pediatric mental health. The difference in "one-on-one" care is the use of harm reduction strategies in the case of children and adolescents with issues related to the abuse of alcohol and other drugs.

Another difference between the production of care in these cases is the way the service is used. Children and adolescents with issues associated with the use of alcohol and other drugs often go to the clinic when their basic needs are unmet. These opportunities are then used by health professionals to implement interventions:

Because these clients [children and adolescents who use alcohol and other drugs], they don't schedule appointments, they just come and say:"Hey, I want a snack. I want to have lunch. I need a shower". That's the only reason they come. So we take it from there. We talk, we carry out interventions, and bond with them. (S. 7)

This approach is in sharp contrast with traditional clinical practice, and reflects the creation of new forms of work organization. According to Sousa (2010), the aim of the CAPS is to develop a model of clinical care that is more fluid and diverse, so it can act in more complex 
situations where traditional approaches are insufficient. To achieve this goal, the service must also have a different physical structure, allowing users and professionals to circulate more freely and make better use of the available space. As such, although a private place for listening sessions is still required, the clinical work can be performed in the most diverse situations, in an innovative and inventive way.

\section{Final Considerations}

The aim of this article was to analyze the perceptions of health care professionals of the effects of a merger between a CAPS ADi and a CAPSi on the process of work and, consequently, on the production of care. The results showed that the exclusion of professionals from the planning of the merger reflected on their work. Its repercussions included difficulties in adopting an interdisciplinary approach to multidisciplinary work; lack of commitment; and a division of the work according to patient needs. Some professionals would only care for individuals with mental disorders, while others would only deal with those whose issues were related to the use of alcohol and other drugs.

Service users and their families were also excluded from the planning of the merger. This indicates a departure from the co-management model, which aims to strengthen social participation through the inclusion of health care users in the planning, implementation and assessment of health production processes (Ministry of Health, 2009a), The inclusion of service users and their families in the discussion and planning of the merger might also have reduced negative connotations and reduced the stigma shown by these individuals. Nevertheless, as reported in our results and discussions, it appears that the personal contact between both populations attending the CAPSi helped decrease the stigma surrounding children and adolescents with mental disorders and issues associated with the use of alcohol and other drugs.

In conclusion, it appears that the difficulties in the work process at the service would be lessened if all those involved in the production of care were included in discussions regarding the merger, and a new institutional approach replaced the vertical structure by opportunities to question and discuss the work process. These opportunities would facilitate the sharing of responsibility in the production of care, improve the interaction between health professionals and, consequently, facilitate teamwork, in addition to increasing the bond betwen service users, their families and health professionals.

It is important to note that the management team who discussed and decided on the merging of the CAPS ADi and the CAPSi, or the service users and their families, were not included in the present study. As a result, their perspective on how these events unfolded could not be analyzed.

\section{References}

Avellar, L. Z., \& Bertollo, M. (2008) A saúde mental na infância e adolescência e o diálogo necessário entre as dimensões clínica, ética e política. In E. M. Rosa, L. Souza, \& L. Z. Avellar (Eds.), Psicologia Social: Temas em debate (pp. 68-87). Vitória, ES: Universidade Federal do Espírito Santos.

Bardin, L. (2006). Análise de conteúdo (L. de A. Rego $\&$ A. Pinheiro, Trans.). Lisboa: Edições 70.

Belotti, M., \& Lavrador, M. C. C. (2016). A prática do apoio matricial e os seus efeitos na Atenção Primária à Saúde. Cadernos de Terapia Ocupacional - UFSCar, 24(2), 373-378. doi:10.4322\%2F0104-4931.ctoRE0627

Busanello, J., Lunardi, W. D., Filho, Kerber, N. P. C., Santos, S. S. C., Lunardi, V. L., \& Pohlmann, F. C. (2013). Grupo focal como técnica de coleta de dados. Cogitare Enfermagem, 18(2), 358-364. doi:10.5380/ce.v18i2.32586

Cavalcante, C. M., Jorge, M. S. B., \& Santos, D. C. M. dos. (2012). Onde está a criança?: Desafios e obstáculos ao apoio matricial de crianças com problemas de saúde mental. Physis: Revista de Saúde Coletiva, 22(1), 161-178. doi:10.1590/ S0103-73312012000100009

Couto, M. C. V. (2012). Politica de Saúde Mental para crianças e adolescentes: Especificidades e desafios da experiência brasileira (2001-2010) 
(Doctoral dissertation, Instituto de Psiquiatria, Universidade Federal do Rio de Janeiro, RJ, Brazil).

Cunha, P. F., \& Magajewski, F. (2012). Gestão participativa e valorização dos trabalhadores: Avanços no âmbito do SUS. Saúde e Sociedade, 21(Suppl. 1), 71-79. doi:10.1590/S010412902012000500006

Faria, H. P., Werneck, M. A. F., Furquim, M. A., Santos, M. A., \& Teixeira, P. F. (2009). Processo de trabalho em saúde (2nd ed.). Belo Horizonte, MG: Nescon.

Franco, T. B., \& Merhy, E. E. (2012). Cartografias do Trabalho e Cuidado em Saúde. Revista Tempus Actas de Saúde Coletiva, 6(20), 151-163. doi:10.18569/tempus.v6i2.1120

Guerra, A. M. C. (2005). A psicanálise no campo da saúde mental infanto-juvenil. Psyché, 9(15), 139-154. Retrieved from http://pepsic.bvsalud. org/scielo.php?script=sci_arttext\&pid=S1415$11382005000100011 \& \operatorname{lng}=\mathrm{pt} \& \mathrm{nrm}=\mathrm{i} \& \mathrm{t} \operatorname{lng}=\mathrm{pt}$

Lima, R. C. (2014). Saúde mental na infância e adolescência. In M. A. S. Jorge, M. C. de A. Carvalho, \& P. R. F. Silva (Eds.), Políticas e Cuidados em Saúde Mental: Contribuições para a prática profissional (pp. 229-254). Rio de Janeiro, RJ: Fundação Oswaldo Cruz.

Littike, D., \& Sodré, F. (2015). Arte do Improviso: O processo de trabalho dos gestores de um hospital universitário federal. Ciência \& Saúde Coletiva, 20(10), 3051-3062. doi:10.1590/1413812320152010.00042015

Luzio, C. A., \& Sinibaldi, B. (2012). Atenção Psicossocial e Psicologia: Um mapeamento da produção científica. Revista de Psicologia da UNESP, 12(2), 99-110. Retrieved from http:// seer.assis.unesp.br/index.php/revpsico/article/ view/27/24

Minayo, M. C. de S. (2012). Análise qualitativa: Teoria, passos e fidedignidade. Ciência \& Saúde Coletiva, 17(3), 621-626. doi:10.1590/S141381232012000300007

Ministry of Health. (2009a). Politica Nacional de Humanização da Atenção e Gestão do SUS. Brasília, DF: Author. Retrieved from http://bvsms. saude.gov.br/bvs/publicacoes/humaniza_sus_atencao_basica.pdf

Ministry of Health. (2009b). A experiência brasileira em sistemas de informação em saúde. Brasília,
DF: Author. Retrieved from http://bvsms.saude. gov.br/bvs/publicacoes/experiencia_brasileira sistemas_saude_volume1.pdf

Ministry of Health. (2009c). Portaria 1.190, de 4 de junho de 2009. Institui o Plano Emergencial de Ampliação do Acesso ao Tratamento e Prevenção em Álcool e outras Drogas no Sistema Único de Saúde - SUS (PEAD 2009-2010) e define suas diretrizes gerais, ações e metas. Brasília, DF: Author. Retrieved from http:// bvsms.saude.gov.br/bvs/saudelegis/gm/2009/ prt1190_04_06_2009.html

Ministry of Health. (2014). Atenção psicossocial a crianças e adolescentes no SUS: Tecendo redes para garantir direitos (Versão preliminar). Brasília, DF: Author. Retrieved from http://bvsms. saude.gov.br/bvs/publicacoes/atencao_psicossocial_criancas_adolescentes_sus.pdf

Morschel, A., \& Barros, E. B. (2014). Processos de trabalho na saúde pública: Humanização e efetivação do Sistema Único de Saúde. Saúde e Sociedade, 23(3), 928-941. doi:doi.org/10.1590/ S0104-12902014000300016

Nardi, H. C. (2006). Ética, trabalho e subjetividade: Trajetórias de vida no contexto do capitalismo contemporâneo. Porto Alegre, RS: Universidade Federal do Rio Grande do Sul.

Resolution no. 466. (2012). Regulamenta pesquisas em seres humanos no Brasil e da outras disposições. Brasília, DF: National Health Council. Retrieved from http:/conselho.saude.gov.br/ resolucoes/2012/Reso466.pdf

Ronzani, T. M., \& Andrade, T. M. (2014). A estigmatização associada ao uso de substâncias como obstáculo à detecção, prevenção e tratamento. In Uso de substâncias psicoativas no Brasil (5rd ed.). Brasília, DF: Secretaria Nacional de Políticas sobre Drogas.

Rüsch, N., Angermeyer, M. C., \& Corrigan, P. W. (2005). Mental illness stigma: Concepts, consequences and initiatives to reduce stigma. $E u$ ropean Psychiatry, 20, 529-539. doi:10.1016/j. eurpsy.2005.04.004

Sousa, P. S. M. (2010). A inserção da psicanálise na saúde mental da reforma psiquiátrica brasileira: Possibilidades e desafios (Master's thesis, Programa de Pós-Graduação em Psicologia Clínica e Cultura, Universidade Federal de Brasília, DF, Brazil). 

and Youth.

Sousa, I. F. de, \& Bastos, P. R. H. de O. (2016). Interdisciplinaridade e formação na área de farmácia. Trabalho, Educação e Saúde, 14(1), 97-117. doi:10.1590/1981-7746-sip00092

Tavares, S. O., Vendrúscolo, C. T., Kostulski, C. A., \& Gonçalves, C. dos S. (2012). Interdisciplinaridade, multidisciplinaridade ou transdisciplinaridade. In Anais do $5^{\circ}$ Interfaces no fazer psicológico. Santa Maria, RS: Centro Universi- tário Franciscano. Retrieved from http://www. unifra.br/eventos/interfacespsicologia/consulta_anais.asp

Received: 03/11/2015

$1^{\text {st }}$ revision: $07 / 07 / 2016$

$2^{\text {nd }}$ revision: $18 / 07 / 2016$

Accepted: 03/08/2016 